\title{
Association between Food Habits and Nutritional Status of Secondary School Students in Kuala Lumpur, Malaysia: Baseline Findings from Nuteen Project
}

\author{
U VAIDEHI, S SHASHIKALA* and K MIRNALINI \\ Faculty of Applied Sciences, UCSI University, Kuala Lumpur 56000, Malaysia
}

(Received June 14, 2019)

\begin{abstract}
Summary Dietary habits and choice of food influences nutritional status of adolescence. Malnutrition have been associated with adolescents' dietary habits that may predispose to chronic disease during their adulthood. The aim of this study is to determine the association between food habit and nutritional status of adolescents. In the baseline study, a total of 924 students from 10 secondary schools were randomly selected from a total of 62 secondary schools in Kuala Lumpur. The students were assessed on various dietary components including food habits using a structured questionnaire as well as for anthropometry measurements. All data were analyzed using SPSS 23 . The prevalence of obesity was significantly higher among males compared to females $\left(16.4 \%\right.$ vs. $\left.8.4 \%, X^{2}=25.42, p<0.001\right)$. Food habit exhibits an inversed association with z-score of body mass index for age $(\beta=-0.107,95 \% \mathrm{CI}=-0.053,-0.013)$, especially via food habits such as often eat dinner $(r=-0.102, p=0.002)$, often have breakfast before school $(r=-0.100, p=0.002)$, often eat cake or dessert at meal $(r=-0.110, p=0.001)$, often drink eight glasses of water $(r=0.132$, $p<0.001)$, often eat food from school canteen $(r=-0.071, p=0.031)$ and often bring own snack from home $(r=-0.112, p=0.001)$. This study suggested that the type of food and timing of meal should be considered to prevent obesity among adolescents.
\end{abstract}

Key Words food habit, nutritional status, secondary school, body mass index for age, Malaysia

Adolescence is a life phase which transitions between childhood and adulthood. It initiates the development of secondary sexual characteristics and ends after the achievement of adult status (1). The phase involves changes in physical, emotional, and cognitive functions (2). This is the second phase of rapid growth, catering to those with a lack of development before entering adulthood. Insufficient nutrient intake significantly impacted the growth in this period and delayed the onset of puberty, as nutrient needs are much higher for this group. In addition to unhealthy food, excessive food intake will negatively affect health as well (3).

The nutritional requirement for adolescents is the highest across the lifespan. In 2017, approximately 7 in 10 adolescents skipped breakfast regularly, 5 in 10 skipped lunch and 5 in 10 skipped dinner regularly. The reasons given for skipped breakfast was no time, no appetite and no food available. One in three Malaysian adolescents consumed carbonated soft drinks at least once daily and male adolescents consumed more frequently than the female adolescents (4). The previous study from Jawatankuasa Penyelaras Kebangsaan untuk Makanan dan Pemakanan (5) found that adolescents did not meet the dietary requirements because of their unhealthy eating behaviours $(6,7)$. Unhealthy

\footnotetext{
*To whom correspondence should be addressed.

E-mail: shashikala@ucsiuniversity.edu.my
}

eating behaviours of adolescents include eating snacks that are high in sugar and fat and leading a sedentary lifestyle. There was only $45 \%$ of Malaysian students are physically active (4). Levels of physical activity tend to decrease among adolescents and this might carry on into adulthood (8). A sedentary lifestyle and unhealthy dietary practices are predictors of obesity among adolescents (9).

Higher intakes of unhealthy food which comprised of high calories, fat and sugar content, is associated with increased body weight and higher body mass index (10, 11). Umairah and colleagues (12) had stated that the prevalence of overweight adolescents has increased between 1997 and 2007 from 9.5\% to 19.6\%. Kelder and colleagues (13) estimated that students will suffer from obesity-related health complications (25 in every 100 students), according to the consistent yearly $1 \%$ increase in the number of overweight students. The initiation of various diseases in adolescence, and progressive obesity from childhood through adulthood, were reported in many current findings across several countries, especially in Malaysia. Therefore, it is very important that healthful nutrition and lifestyle behaviours are adopted at a young age (14). One of the causes of excessive adiposity among children and adolescents is the availability of energy-dense foods and beverages in their environment such as home and school.

There is a limited choice of healthy food sold in school 
canteens in Malaysia. The canteens sold and served high fat foods like rice cooked in coconut milk, fried foods, deep fried snacks, sweet drinks, and assorted other unhealthy choices, which have been significantly associated with weight problems among school children. In another study, food sold in the school selected was nuggets, hot dogs, burgers, sweet drinks, sweets, snacks, and instant noodles, also identified as unhealthy $(12,15)$. Fast foods and other foods, including snacks, chocolate, and confections, are the most profitable items sold in the canteen. Food bought from the school canteen provided more fat than food brought from home (16). Consistently, the consumption of energy-dense foods and beverages significantly contributed to the total energy consumption at school versus outside of school (17). Hence, the present study was conducted to examine and understand the eating habits among Malaysian adolescents in selected secondary schools.

\section{MATERIALS AND METHODS}

Nutritional Canteen Intervention for Teenagers (NuTeen) was a three-year randomised controlled intervention trial based on the Precede-Proceed Model in selected secondary schools in Kuala Lumpur among students, parents, teachers, and school canteen operators involving mixed quantitative and qualitative methods. Phase I of the study was conducted in 2015, while Phase II and Phase III were conducted in 2016 and 2017, respectively. The NuTeen study was approved by the Ministry of Education, Malaysia. This study was funded by the E Science Fund by Ministry of Science, Technology, and Innovation (MOSTI) (06-02-22-SF 0003). This intervention study was registered under clinical trial registry UMIN (R000030148 UMIN 000027702).

In Phase I, ten secondary schools were randomly selected from a total of 62 secondary schools in Kuala Lumpur. From each school, three classes were randomly selected from each form and all of these students were invited to participate. Students were defined as secondary school students aged between 13 and $17 \mathrm{y}$ from forms 1, 2, and 4. Students in form 3 (15 y old) and form 5 (17 y old) who were involved in national examinations like Pentaksiran Tingkatan Tiga (PT3) or Sijil Peperiksaan Malaysia (SPM) were not included in this study. Sample size for this study was calculated based on Daniels (1999) formula using the prevalence of obesity among adolescents (11.9\%) from National Health Morbidity Survey (NHMS, 2017). The estimated sample size was 950 adolescents with additional of $20 \%$ of drop-out rate. After eliminating missing data, a total of 924 samples were used for statistical analysis. Before informed consents were obtained from the participants, information sheets explaining the study purpose and its protocol were distributed and explained to them.

PRECEDE was used as a planning model for this study. The first half of the model PRECEDE consists of baseline data collection on the situational analysis, social, epidemiological, educational, and ecological assessment. The data were utilised to generate information as a guide to develop intervention strategies. The underlying approach of this model begins by identifying strategies to reduce the proportion of high energy-dense foods and beverages sold in the school canteen, to improve the knowledge, attitude, and practice of healthy eating for subsequent improvement in the nutritional status of the adolescents.

A self-administrative questionnaire was distributed to each participating student. Socio-demographic information including date of birth, age, ethnicity, pocket money per month, parental educational level and parental occupation were assessed by self-report. Eating habits of the adolescents were assessed using a selfadministered Eating Habits questionnaire which were adapted from $(18,19)$. A total of 28 questions were categorized into two parts, ie. frequency of different type of food consumed and food habits. The questionnaire assessed on various dietary components including food habits and nutritional status. Mean was calculated according to the frequency in a week, eg everyday intake was calculated as $5 / 7 \mathrm{~d}, 2-5$ times per week as 3.5/7 d and once was $1 / 7 \mathrm{~d}$. Body weight and height, waist circumference, hip circumference, and body fat percentages, were measured. Body mass index was calculated as $\mathrm{kg} / \mathrm{m}^{2}$ and nutritional status of the participant was classified based on WHO, 1995 (20) criteria. Body weight was measured by using a TANITA digital weighing scale to the nearest $0.1 \mathrm{~kg}$ and height was assessed by using a SECA body meter to the nearest $0.1 \mathrm{~cm}$.

All statistical analyses were conducted using SPSS for Windows version 23. Descriptive statistics such as frequencies, means, standard deviations and percentage was used to describe all the variables. Chi square and multiple logistic regression was used for the analyses. A statistical probability level of $p<0.05$ was considered as significant.

\section{RESULTS}

Table 1 shows the distribution of demographic characteristics of students. Majority of study respondents were female (53.1\%), 14 y old (36.1\%), Malays (53.7\%) and having monthly allowance of RM100-300 $(40.5 \%)$. Majority of the parents' of the study respondents were married $(88.1 \%)$ and having secondary school background $(58.4 \%$ for father and $55.6 \%$ for mother). Most of the fathers are professionals (51.6\%), while most of the mothers are working as non-professionals $(65.5 \%)$. Table 2 shows the body weight status between male and female students. There were 8 students aged $15 \mathrm{y}$ in Form 2 and 8 students in Form 4 aged $17 \mathrm{y}$. The prevalence of obesity was significantly higher among males as compared to females (16.4\% vs. $\left.8.4 \%, X^{2}=25.42, p<0.001\right)$. Table 3 shows the responses and mean score of for each food habit. Based on the mean score, in average the students frequently eat lunch $($ mean $=0.797 \pm 0.297)$ and eat dinner $($ mean $=$ $0.795 \pm 0.309)$. Only small proportion of students consume vegetables and fruits everyday $(10.9 \%$ and $19.7 \%$, respectively). Only $5.1 \%$ of the students brought own 
Table 1. Distribution of demographic characteristics of students and parents.

\begin{tabular}{|c|c|c|}
\hline Variables & $\begin{array}{c}\text { Frequency } \\
(n=924)\end{array}$ & $\begin{array}{c}\text { Percentage } \\
(\%)\end{array}$ \\
\hline \multicolumn{3}{|l|}{ Gender } \\
\hline Male & 433 & 46.9 \\
\hline Female & 491 & 53.1 \\
\hline \multicolumn{3}{|l|}{ Age $(y)$} \\
\hline 13 & 319 & 34.5 \\
\hline 14 & 334 & 36.1 \\
\hline 15 & 8 & 0.9 \\
\hline 16 & 255 & 27.6 \\
\hline 17 & 8 & 0.9 \\
\hline \multicolumn{3}{|l|}{ Ethnicity } \\
\hline Malay & 496 & 53.7 \\
\hline Chinese & 292 & 31.6 \\
\hline Indian & 116 & 12.6 \\
\hline Others & 20 & 2.2 \\
\hline \multicolumn{3}{|l|}{ Pocket Money (RM) } \\
\hline$<100$ & 502 & 54.3 \\
\hline $100-300$ & 374 & 40.5 \\
\hline $301-500$ & 26 & 2.8 \\
\hline $501-700$ & 3 & 0.3 \\
\hline$>700$ & 19 & 2.1 \\
\hline \multicolumn{3}{|c|}{ Parent's marital status $(n=686)^{\mathrm{a}}$} \\
\hline Single & 26 & 3.7 \\
\hline Married & 622 & 88.1 \\
\hline Separated/divorced & 38 & 5.4 \\
\hline \multicolumn{3}{|l|}{ Father's educational level } \\
\hline No formal education & 13 & 1.4 \\
\hline Primary & 47 & 5.1 \\
\hline Secondary & 540 & 58.4 \\
\hline Diploma & 165 & 17.9 \\
\hline Bachelor degree & 125 & 13.5 \\
\hline Masters degree and above & 34 & 3.7 \\
\hline \multicolumn{3}{|l|}{ Mothers educational level } \\
\hline No formal education & 13 & 1.4 \\
\hline Primary & 61 & 6.6 \\
\hline Secondary & 514 & 55.6 \\
\hline Diploma & 188 & 20.3 \\
\hline Bachelor degree & 118 & 12.8 \\
\hline Masters degree and above & 30 & 3.2 \\
\hline \multicolumn{3}{|l|}{ Father's occupation } \\
\hline Professional & 477 & 51.6 \\
\hline Non-professional & 447 & 48.4 \\
\hline \multicolumn{3}{|l|}{ Mother's occupation } \\
\hline Professional & 319 & 34.5 \\
\hline Non-professional & 605 & 65.5 \\
\hline
\end{tabular}

${ }^{\mathrm{a}}$ Missing 238.

Table 2. Body weight status between male and female students.

\begin{tabular}{lcccc}
\hline \multicolumn{1}{c}{$\begin{array}{c}\text { Body Mass } \\
\text { Index }\end{array}$} & $\begin{array}{c}\text { Male } \\
n(\%)\end{array}$ & $\begin{array}{c}\text { Female } \\
n(\%)\end{array}$ & $\mathrm{X}^{2}$ & $p$-value \\
\hline Severe thinness & $12(2.8)$ & $2(0.4)$ & 25.42 & $<0.001$ \\
Thinness & $12(2.8)$ & $18(3.7)$ & & \\
Normal & $261(60.3)$ & $348(70.9)$ & & \\
Overweight & $77(17.8)$ & $82(16.7)$ & & \\
Obese & $71(16.4)$ & $41(8.4)$ & & \\
& & & &
\end{tabular}

snack or lunch box to school.

Table 4 shows the multiple linear regression analysis assessing the association between Food habit and body mass index for age. Food habit exhibit an inversed association with z-score of body mass index for age $(\beta=$ $-0.107,95 \% \mathrm{CI}=-0.053,-0.013)$, especially via food habits such as often eat dinner $(r=-0.102, p=$ $0.002)$, often have breakfast before school $(r=-0.100$, $p=0.002)$, often eat cake or dessert at meal $(r=-0.110$, $p=0.001)$, often drink eight glasses of water $(r=0.132$, $p<0.001)$, often eat food from school canteen $(r=$ $-0.071, p=0.031)$ and often bring own snack from home $(r=-0.112, p=0.001)$.

\section{DISCUSSION}

In this study, prevalence of obesity was significantly higher among males compared to females. The current finding was consistent with several studies conducted in Malaysia adolescents where they also found higher proportion of obese adolescents compared to female (21, 22 ). The higher prevalence of obesity among male adolescents may be due to higher dietary energy intake compared to female adolescents. This was evident in several studies including the national nutrition survey conducted in Malaysia which showed that a daily median energy intake of food among male was 1,489 $\mathrm{kcal} / \mathrm{d}$ which was higher than median energy intake than female $(1,445 \mathrm{kcal} / \mathrm{d})$ (21). Similarly, another study reported that average intake of dietary energy among males was $1,774 \mathrm{kcal} / \mathrm{d}$ compared to females which was $1,595.2 \mathrm{kcal} / \mathrm{d}$ (24). Higher energy intake may enhance positive energy balance in the body, thus the consequence is an increase in body mass (25). An in vivo study showed that increased in dietary energy especially from fat may increase 50 percent of fat content in the body (23).

In this study, only small proportion of students consume vegetables and fruits every day. Studies consistently showed that low vegetables and fruits intake had increased the energy intake of adolescents $(26,27)$. A study suggested that increasing portion sizes of fruits and vegetables in an elementary school lunch program can increase fruit and vegetable consumption (28). Only $5.1 \%$ of the students brought own snack or lunch box to school. This is in contrast to a study conducted in U.K. which reported that over half of $(>50 \%)$ of the adolescents brought home packed food or lunch box. However, the authors found that the total energy and nutrients from the home packed food or lunch box did not meet the nutrient based standard for adolescents (29). Food brought to school or prepared at home usually have higher dietary quality and usually wholesome food. Parents have to play important role in preparing homemade food to provide good quality of food as well as meet the recommended nutrient intake for adolescents. Food habit exhibit an inversed association with z-score of body mass index for age. It is hypothesized that a good food habit able to avoid weight gain and retained a health body mass index for age.

There are significant inverse association between 
Table 3. Responses and mean score of weekly frequency of food habit.

\begin{tabular}{|c|c|c|c|c|c|c|}
\hline \multirow{2}{*}{ Food habit } & \multicolumn{4}{|c|}{ Frequency (weekly) $n(\%)$} & \multirow{2}{*}{ Mean } & \multirow{2}{*}{ SD } \\
\hline & Never & $1 \mathrm{x}$ & $2-5 x$ & Everyday & & \\
\hline Eating breakfast & $\begin{array}{c}69 \\
(7.5)\end{array}$ & $\begin{array}{c}116 \\
(12.6)\end{array}$ & $\begin{array}{c}240 \\
(26.0)\end{array}$ & $\begin{array}{c}499 \\
(54.0)\end{array}$ & 0.688 & 0.367 \\
\hline Eating lunch & $\begin{array}{c}14 \\
(1.5)\end{array}$ & $\begin{array}{c}61 \\
(6.6)\end{array}$ & $\begin{array}{c}242 \\
(26.2)\end{array}$ & $\begin{array}{c}607 \\
(65.7)\end{array}$ & 0.797 & 0.297 \\
\hline Eating dinner & $\begin{array}{c}24 \\
(2.6)\end{array}$ & $\begin{array}{c}65 \\
(7.0)\end{array}$ & $\begin{array}{c}220 \\
(23.8)\end{array}$ & $\begin{array}{c}615 \\
(66.6)\end{array}$ & 0.795 & 0.309 \\
\hline Eating breakfast before going to school & $\begin{array}{c}164 \\
(17.7)\end{array}$ & $\begin{array}{c}129 \\
(14.0)\end{array}$ & $\begin{array}{c}227 \\
(24.6)\end{array}$ & $\begin{array}{c}404 \\
(43.7)\end{array}$ & 0.580 & 0.407 \\
\hline Eating at least 2 servings or cups ( $300 \mathrm{~g}$ ) of fruit & $\begin{array}{c}134 \\
(14.5)\end{array}$ & $\begin{array}{c}339 \\
(36.7)\end{array}$ & $\begin{array}{c}350 \\
(37.9)\end{array}$ & $\begin{array}{c}101 \\
(10.9)\end{array}$ & 0.350 & 0.298 \\
\hline Eating at least 3 servings or cups ( $225 \mathrm{~g}$ ) of vegetables & $\begin{array}{c}121 \\
(13.1)\end{array}$ & $\begin{array}{c}258 \\
(27.9)\end{array}$ & $\begin{array}{c}363 \\
(39.3)\end{array}$ & $\begin{array}{c}182 \\
(19.7)\end{array}$ & 0.434 & 0.337 \\
\hline Eating a cake or a dessert at meals & $\begin{array}{c}341 \\
(36.9)\end{array}$ & $\begin{array}{c}374 \\
(40.5)\end{array}$ & $\begin{array}{c}160 \\
(17.3)\end{array}$ & $\begin{array}{c}49 \\
(5.3)\end{array}$ & 0.196 & 0.257 \\
\hline Drinking beverage at meals & $\begin{array}{c}113 \\
(12.2)\end{array}$ & $\begin{array}{c}151 \\
(16.3)\end{array}$ & $\begin{array}{c}222 \\
(24.0)\end{array}$ & $\begin{array}{c}438 \\
(47.4)\end{array}$ & 0.617 & 0.396 \\
\hline Drinking $2 \mathrm{~L}$ or 8 glasses of water every day & $\begin{array}{c}82 \\
(8.9)\end{array}$ & $\begin{array}{c}133 \\
(14.4)\end{array}$ & $\begin{array}{c}353 \\
(38.2)\end{array}$ & $\begin{array}{c}356 \\
(38.5)\end{array}$ & 0.597 & 0.358 \\
\hline Eating food from school canteen & $\begin{array}{c}91 \\
(9.8)\end{array}$ & $\begin{array}{c}205 \\
(22.2)\end{array}$ & $\begin{array}{c}441 \\
(47.7)\end{array}$ & $\begin{array}{c}187 \\
(20.2)\end{array}$ & 0.472 & 0.321 \\
\hline Eating food at home & $\begin{array}{c}122 \\
(13.2)\end{array}$ & $\begin{array}{c}124 \\
(13.4)\end{array}$ & $\begin{array}{c}218 \\
(23.6)\end{array}$ & $\begin{array}{c}460 \\
(49.8)\end{array}$ & 0.635 & 0.396 \\
\hline Bring own snack or lunch box to school & $\begin{array}{c}513 \\
(55.5)\end{array}$ & $\begin{array}{c}239 \\
(25.9)\end{array}$ & $\begin{array}{c}125 \\
(13.5)\end{array}$ & $\begin{array}{c}47 \\
(5.1)\end{array}$ & 0.155 & 0.257 \\
\hline
\end{tabular}

Table 4. Multiple Linear Regression assessing the association between food habit and body mass index for age.

\begin{tabular}{|c|c|c|c|c|c|}
\hline \multirow{2}{*}{ Food habit } & \multirow{2}{*}{$r$} & \multirow{2}{*}{$p$-value } & \multirow{2}{*}{ Adjusted- $\beta^{\mathrm{a}}$} & \multicolumn{2}{|c|}{$95 \% \mathrm{CI}$} \\
\hline & & & & Lower bound & Upper bound \\
\hline Overall food habit & & & -0.107 & -0.05 & -0.01 \\
\hline Eating breakfast & -0.062 & 0.059 & 0.018 & -0.110 & 0.165 \\
\hline Eating lunch & -0.031 & 0.351 & 0.017 & -0.118 & 0.191 \\
\hline Eating dinner & -0.120 & $0.002^{* *}$ & -0.091 & -0.320 & $-0.040^{*}$ \\
\hline Eating breakfast before going to school & -0.100 & $0.002^{* *}$ & -0.100 & -0.242 & $-0.016^{*}$ \\
\hline Eating at least 2 servings or cups ( $300 \mathrm{~g}$ ) of fruit & -0.040 & 0.221 & -0.015 & -0.157 & 0.106 \\
\hline Eating at least 3 servings or cups ( $225 \mathrm{~g}$ ) of vegetables & -0.035 & 0.285 & -0.022 & -0.152 & 0.084 \\
\hline Eating a cake or a dessert at meals & -0.110 & $0.001^{* *}$ & -0.077 & -0.242 & -0.019 \\
\hline Drinking beverage at meals & -0.043 & 0.196 & -0.040 & -0.145 & 0.034 \\
\hline Drinking 2 L or 8 glasses of water every day & 0.132 & $<0.001^{* *}$ & 0.162 & 0.149 & 0.355 \\
\hline Eating food from school canteen & -0.071 & $0.031^{*}$ & -0.057 & -0.202 & 0.012 \\
\hline Eating food at home & 0.010 & 0.771 & 0.013 & -0.071 & 0.106 \\
\hline Bring own snack or lunch box to school & -0.112 & $0.001^{* *}$ & -0.086 & -0.250 & -0.035 \\
\hline
\end{tabular}

\footnotetext{
** Correlation is significant at the 0.01 level (2-tailed).

* Correlation is significant at the 0.05 level (2-tailed).

${ }^{\text {a }}$ Multiple linear regression.
}

often eat dinner, often have breakfast before school, often eat cake or dessert at meal, often eat food from school canteen,often bring own snack from home and body weight status. Meal consumption patterns, such as meal frequency and breakfast consumption has become a significant contributing factor in childhood obesity. Breakfast skipping has been independently associated with obesity among children. In addition, reduction in the frequency of other meal consumption (lunch and dinner) positively related with childhood obesity (31). MyBreakfast Study from Malaysia found that overall prevalence of breakfast skipping and irregular break- 
fast consumption was associated with higher Body mass index for age $\mathrm{z}$ score and greater likelihood of being overweight and obese among adolescents especially in girls. This association is plausible as skipping breakfast able to enhance appetite for the next meal which consequently increase the energy intake creating the state of energy imbalance which is highly associated with increased body mass index. Study showed that children or adolescents who consume breakfast are more likely to get food high in fiber, calcium and other important nutrients (30). These type of breakfast food may improve postprandial glycaemic responses, insulin sensitivity and satiety (32).

The inverse association between having cake or dessert at meal with body weight status of adolescents could be explained based on the healthy ingredients used during cake or dessert making. Commonly children or adolescents prefer fruit based cakes or desserts such as carrot cake, banana cake, or pudding which composed of a small amount of starch and fiber mainly insoluble fiber. This could be a better option as low dense food (33). Adolescents often eat food from school canteen especially for lunch if there are extra classes or co-curicular activities in school. This was significantly associated with reduced body mass index. In UK (29) found that students taking school lunches on average had significantly higher intakes of energy, protein, carbohydrate, Vitamin C,folate, ferum and zinc compared to those bringing packed lunch to school. Higher density of energy and nutrients were consistently linked with increased body weight in several studies (34-36). Bringing own snack from home is associated inversely with weight status. Bringing snack from home would be ideal because food availability at home is controlled by parents. Parents will be more likely to prepare healthier snacks at home which comprised of low energy dense type of food or beverages which will not be contributing to the overall energy intake for development of obesity among adolescents (37-39).

\section{CONCLUSION}

This study suggested that the type of food (cake or dessert; food from canteen and own snack from home) and timing of meal (breakfast and dinner) should be considered to prevent obesity among adolescents. It is suggested that a healthy school food environment and parent's commitment to provide healthy food may act as the most effective strategies to intervene the obesity among adolescents.

\section{Disclosure of state of COI}

The authors declare no conlict of interest.

\section{Acknowledgments}

The E-Science Fund by the Ministry of Science, Technology, and Innovation (MOSTI) (06-02-22-SF0003 provided financial support for the study. The authors wish to acknowledge and thank schools, teachers, students, parents, and canteen operators in the NuTeen Project.

\section{REFERENCES}

1) Cowan PA, Hetherington EM. 2013. Individual and family life transitions: A proposal for a new definition. In Family transitions 15-42. Routledge.

2) Savige G, MacFarlane A, Ball K, Worsley A, Crawford D. 2007. Snacking behaviours of adolescents and their association with skipping meals. Int J Behav Nutr Phys Act $\mathbf{4}(1)$ : 36.

3) Adesina A, Peterside O, Anochie I, Akani N. 2012. Weight status of adolescents in secondary schools in port Harcourt using Body Mass Index (BMI). Ital J Pediatr 38: 31.

4) IPH. 2017. National Health and Morbidity Survey 2017 (NHMS 2017) Kuala Lumpur: Institute of Public Health.

5) Jawatankuasa Penyelaras Kebangsaan Untuk Makanan Dan Pemakanan (NCCFN). 2017. Available at: http:// nutrition.moh.gov.my/en/jawatankuasa-penyelaras-kebangsaan-untuk-makanan-dan-pemakanan-nccfn/ (Accessed: 3 May 2018).

6) Rezali F, Chin Y, Mohd Yusof B. 2012. Obesity-related behaviors of Malaysian adolescents: a sample from Kajang district of Selangor state. Nutr Res Pract 6(5): 458-465.

7) Chin Y, Mohd Nasir M. 2009. Eating behaviors among female adolescents in Kuantan District, Pahang, Malaysia. Pak J Nutr 8: 425-432.

8) Tammelin T, Naysha S, Hills A, Jarvelin M. 2003. Adolescent participation in sports and adult physical activity. Am J Prev Med 24(1): 22-28.

9) Jebb S. 2007. Dietary determinants of obesity, Obes Rev 8(1): 93-97.

10) Nicklas T, Yang S, Baranowski T, Zakeri I, Berenson G. 2003. Eating patterns and obesity in children. The Bogalusa Heart Study. Am J Prev Med 25(1): 9-16.

11) Rezali F, Chin Y, Mohd Shariff Z, Mohd Yusof B, Sanker K, Woon F. 2015. Evaluation of diet quality and its associated factors among adolescents in Kuala Lumpur, Malaysia. Nutr Res Pract 9(5): 511-516.

12) Sharifah NU, Safiah MY. 2012. Relationship between dietary patterns and body mass index among primary school children. Asian J Clin Nutr 4(4): 142-150.

13) Kelder SH, Hoelscher D, Perry CL. 2015. How individuals, environments, and health behaviors interact. Health behavior: Theory, research, and practice 159 .

14) Singh A, Mulder C, Twisk J, Van Mechelen W, Chinapaw M. 2008. Tracking of childhood overweight into adulthood: a systematic review of the literature. Obes Rev 9(5): 474-488.

15) Moy F, Gan C, Zaleha M. 2004. Body mass status of school children and adolescents in Kuala Lumpur, Malaysia. Asia Pac J Clin Nutr 13(4): 324-329.

16) McKenzie T, Sallis J, Broyles S, Zive M, Nader P, Berry C. 2002. Childhood movement skills: Predictors of physical activity in Anglo American and Mexican American adolescents?. Res Q Exerc Sport 73(3): 238-244.

17) Bell A, Swinburn B. 2004. What are the key food groups to target for preventing obesity and improving nutrition in schools?. Eur J Clin Nutr 58(2): 258-263.

18) Turconi, et al. 2008. Eating habits, behaviors, physical activity, nutritional and food safety knowledge and beliefs in an adolescent Italian population. J Am Coll Nutr 27(1): 31-43.

19) WHO. 2008. Collaborating Centre on Obesity Preven- 
tion \& Related Research and Training Adolescent Behaviors Attitude \& Knowledge Questionnaire (ABAKQ) 2008.

20) World Health Organization. 1995. Physical status: The use and interpretation of anthropometry. Geneva: WHO Technical Series Report No. 854.

21) Abdul Majid H, Ramli L, Ying SP, Su TT, Jalaludin MY, Mohsein A, Al-Sadat N. 2016. Dietary intake among adolescents in a middle-income country: An outcome from the Malaysian Health and Adolescents Longitudinal Research Team Study (the MyHeARTs Study). PLoS One 11(5): e0155447.

22) Ojo QE, Suriani I, Huda BZ, Suhainiza MS. 2019. Predictors of overweight and obesity among secondary school students in Puchong Selangor, Malaysia. International Journal of Public Health and Clinical Sciences 6(4): 160-170.

23) Hu S, Wang L, Yang D, Li L, Togo J, Wu Y, Zhang X. 2018. Dietary fat, but not protein or carbohydrate, regulates energy intake and causes adiposity in mice. Cell Metab 28(3): 415-431.

24) Chan YY, Lim KK, Lim KH, Teh CH, Kee CC, Cheong SM, Ahmad NA. 2017. Physical activity and overweight/ obesity among Malaysian adults: findings from the 2015 National Health and morbidity survey (NHMS). BMC Public Health 17(1): 733.

25) Hill JO, Wyatt HR, Peters JC. 2012. Energy balance and obesity. Circulation 126(1): 126-132.

26) Rezali FW, Chin YS, Yusof M, Nisak B. 2012. Obesity-related behaviors of Malaysian adolescents: a sample from Kajang district of Selangor state. Nutr Res Pract 6(5): $458-465$.

27) Gopinath B, Flood VM, Burlutsky G, Louie JC, Baur LA, Mitchell P. 2016. Frequency of takeaway food consumption and its association with major food group consumption, anthropometric measures and blood pressure during adolescence. Br J Nutr 115(11): 2025-2030.

28) Miller N, Reicks M, Redden JP, Mann T, Mykerezi E, Vickers Z. 2015. Increasing portion sizes of fruits and vegetables in an elementary school lunch program can increase fruit and vegetable consumption. Appetite 91: 426-430.

29) Pearce J, Wood L, Nelson M. 2013. Lunchtime food and nutrient intakes of secondary-school pupils; a compari- son of school lunches and packed lunches following the introduction of mandatory food-based standards for school lunch. Public Health Nutr 16(6): 1126-1131.

30) Fayet-Moore F, Kim J, Sritharan N, Petocz P. 2016. Impact of breakfast skipping and breakfast choice on the nutrient intake and body mass index of Australian children. Nutrients $\mathbf{8}(8)$ : 487.

31) Patro B, Szajewska H. 2010. Meal patterns and childhood obesity. Curr Opin Clin Nutr Metab Care 5(13): 300-304.

32) Tee ES, Nurliyana AR, Norimah K, Hamid Jan MJ, Tan SY, Mahenderan A, Hopkins S, Thielecke F, Ong MK, Ning C, Nasir MT. 2018. Breakfast consumption among Malaysian primary and secondary school children and relationship with body weight status - findings from the Mybreakfast study. Asia Pac J Clin Nutr 27(2): 421-432.

33) Segundo C, Roman L, Lobo M, Martinez MM, Gomez M. 2017. Ripe banana flour as a source of antioxidants in layer and sponge cakes. Plant Foods Hum Nutr 72(12): 365-371.

34) Westerterp KR. 2004. Diet induced thermogenesis. Nutr Metab 1: 5

35) Abete I, Astrup A, Martinez J, Thorsdottir I, Zulet MA. 2010. Obesity and the metabolic syndrome: a role of different dietary macronutrient distribution patterns and specific nutritional components on weight loss and maintainance. Nutr Rev 68: 214-231.

36) World Health Organization (WHO) and Food and Agriculture Organisation (FAO) of the United Nations. Diet nutrition and the prevention of chronic diseases. 2003. Report of a joint WHO/FAO Expert Consultation. WHO Technical Report Series No. 916 WHO: Geneva.

37) Rosenkranz RR, Dzewaltowski DA. 2008. Model of the home food environment pertaining to childhood obesity. Nutr Rev 66: 123-140.

38) Larson N, MacLehose R, Fulkerson JA, Berge JM, Story M. 2013. Eating breakfast and dinner together as a family: associations with sociodemographic characteristics and impications for diet quality and weight status. J Acad Nutr Diet 113: 1601-1609.

39) Couch SC, Glanz K, Zhou C, Sallis JF, Saelens BE. 2014. Home food environment in relation to children's diet quality and weight status. J Acad Nutr Diet 114: 15691579. 